\title{
Involution of the Lactating Mammary Gland Is Inhibited by the IGF System in a Transgenic Mouse Model
}

\author{
Stefan Neuenschwander, Arnold Schwartz, ${ }^{\star}$ Teresa L. Wood, ${ }^{\ddagger}$ Charles T. Roberts, Jr., Lothar Henninghausen, ${ }^{\S}$ \\ and Derek LeRoith \\ Diabetes Branch, National Institute of Diabetes and Digestive and Kidney Diseases, National Institutes of Health, Bethesda, Maryland \\ 20892; *Department of Pathology, George Washington University Medical Center, Washington, DC 20037; Department of Neuroscience \\ and Anatomy, Pennsylvania State University College of Medicine, Hershey, Pennsylvania 17033; and ${ }^{\S}$ Laboratory of Biochemistry and \\ Metabolism, National Institute of Diabetes and Digestive and Kidney Diseases, National Institutes of Health, Bethesda, Maryland 20892
}

\begin{abstract}
Development of the mammary gland during puberty, pregnancy, and lactation is controlled by steroid and peptide hormones and growth factors. To determine the role of the insulin-like growth factors (IGFs) in this process we developed a transgenic model using the whey acidic protein (WAP) gene to direct expression of rat IGF-I and human IGF binding protein-3 (IGFBP-3) to mammary tissue during late pregnancy and throughout lactation.

High levels of expression of transgenic IGF-I and IGFBP-3 were seen in lobular-alveolar cells by in situ hybridization. There was no obvious effect on mammary development during pregnancy and lactation; indeed, mothers were capable of nursing their pups normally and the only structural difference seen in the mammary glands at peak lactation was an overall smaller size of the alveoli. We also evaluated the role of IGF-I and IGFBP-3 in the remodeling of mammary tissue during involution. Compared with control animals, the process of involution was modified in both transgenic lines. The degree of apoptotic cells was lower in the WAPIGF-I and WAP-BP-3 expressing mice. In addition, there was a more quiescent pattern of involution with residual lobular secretory ability and a muted host inflammatory reaction with fewer lumenal microcalcifications.

These results demonstrate that IGF-I and IGFBP-3 may modulate the involutionary process of the lactating mammary gland. (J. Clin. Invest. 1996. 97:2225-2232). Key words: apoptosis - lactation - insulin-like growth factors • transgenic whey acidic protein gene
\end{abstract}

\section{Introduction}

Tissues of the female reproductive system require the coordinated actions of pituitary, ovarian, and adrenal hormones and growth factors for normal development (1). During fetal development, growth factors seem to play a major role in mammary gland development, whereas estrogen, glucocorticoids, and growth hormone are vital for mammary development during puberty (2-4). Insulin, thyroid hormone, and growth fac-

Address correspondence to Derek LeRoith, Diabetes Branch, NIDDK, National Institutes of Health, Bldg. 10, Rm. 8S-235A, Bethesda, MD 20892. Phone: 301-496-8090; FAX: 301-480-4386; E-mail: derek@helix.nih.gov

Received for publication 8 September 1995 and accepted in revised form 14 February 1996.

The Journal of Clinical Investigation

Volume 97, Number 10, May 1996, 2225-2232 tors such as IGF-I, EGF, PDGF, and the TGFs are also important during pubertal development (1-4). These same factors and additional hormones including progesterone and prolactin contribute to pregnancy-induced mammary growth (5). On the other hand, lactation is associated with estrogen and progesterone withdrawal and the presence of insulin, glucocorticoids, and prolactin (1).

Since GH has been shown to regulate IGF-I mRNA levels in the rat mammary gland, it is possible that IGF-I may mediate the effects of $\mathrm{GH}$ on mammary gland development $(6,7)$. IGF-I expressed by stromal cells may act in a paracrine fashion on epithelial cells that express the IGF-I receptor. Furthermore, IGF-binding proteins (IGFBPs) ${ }^{1}$ are expressed by mammary tissue and mammary-derived cell lines and are known to modulate the biological effects of the IGFs (8). IGF-I and the IGFBPs are also found in milk $(9,10)$, originating from the blood or potentially arising from de novo synthesis in the mammary gland. Normal synthesis of IGF-I in the mammary gland is restricted to stromal cells, most likely of fibroblast origin $(11,12)$. The low levels of IGF-I that are normally produced by stromal cells do not appear to explain the levels found in milk, and flux studies clearly indicate that blood is an important contributor to the mammary secretion of IGF-I (13). Mammary alveolar cells synthesize and secrete various combinations of IGFBPs (9) that may be related to the transfer of IGF-I into milk, in addition to their classic functions in modulating local IGF-I action (14).

The purpose of this study was to determine the role of IGFs and IGFBPs on mammary gland development and function during pregnancy and lactation. Using transgenic mice in which either IGF-I or IGFBP-3 was overexpressed in a mammary-specific manner using the whey acidic protein (WAP) gene promoter, we obtained results supporting the hypothesis that the IGF system plays a major role in mammary gland physiology.

\section{Methods}

Recombinant plasmids. A rat preproIGF-I cDNA was removed from pGEM4Z using PvuII and AvaI (15). The resulting fragment consisted of contiguous exon 1, exon 3, exon 4, and exon 6 sequences. The cDNA lacks the 186-bp sequence of exon 1 and exon 5, which are subject to alternative splicing (16). Thus, this cDNA encodes $38 \mathrm{bp}$ of 5'-UTR, 48 amino acids of the IGF-I signal peptide, the 70-amino acid mature IGF-I peptide, the 35-amino acid Ea trailer peptide, and 13 bp of $3^{\prime}$-UTR (17).

1. Abbreviations used in this paper: IGFBP, IGF-binding proteins; WAP, whey acidic protein; WAP-BP-3, whey acidic protein-IGFBP-3 transgene; WAP-IGF-I, whey acidic protein-IGF-I transgene. 
The human IGFBP-3 clone was a gift of Dr. William Wood (Genentech Inc., South San Francisco, CA). The complete open reading frame of hIGFBP-3 includes 116 bp of $5^{\prime}$-UTR and 523 bp of 3'-UTR (18). It was isolated from vector DNA by digestion with SalI and BamHI, gel purified on a $1 \%$ agarose gel, and blunt-ended with Klenow enzyme. The plasmid pBSWAP, containing an $\sim 7.2$-kb EcoRI fragment spanning the mouse WAP gene, was linearized with KpnI (a unique site in the $5^{\prime}$-UTR) (19) and blunt-ended with the Klenow enzyme. Rat IGF-I (rIGF-I) or hIGFBP-3 blunt-ended fragments were ligated into the blunt-ended KpnI site of the WAP gene using T4 DNA ligase. The regions of ligation were sequenced and the sequence was confirmed to be correct. WAP-hybrid genes were separated from vector sequences by digestion with EcoRI, followed by electrophoresis on a $1 \%$ agarose gel. DNA fragments were isolated with the Elu-Quick DNA purification kit (Schleicher \& Schuell, Inc., Keene, $\mathrm{NH}$ ).

Generation of transgenic mice. All the animal studies were approved by the Animal Care and Use Committee of the National Institute of Diabetes and Digestive and Kidney Diseases, National Institutes of Health (Bethesda, MD). The WAP hybrid gene fragments were microinjected into the pronuclei of zygotes obtained from C57BL6/SJL F2 mice (DNX, Princeton, NJ) (20). The embryos were reimplanted into pseudopregnant females and offspring were screened for the transgene by PCR (see below). Transgenic offspring were generated by backcrossing founders to C57BL6 mice.

Transgenic founder mice were identified by PCR analysis of genomic DNA obtained from tail biopsies. The common $5^{\prime}$ sense primer was located in the WAP gene (5'-tagagctgtgccagcctcttc- $\left.3^{\prime}\right)$. A $3^{\prime}$ antisense primer was located in the hIGFBP-3 transgene $\left(5^{\prime}\right.$-tgcaaccggggcacgctgctt- $\left.3^{\prime}\right)$ and in the rIGF-I transgene (5'-cacacacgaactgaagagcgt- $\left.3^{\prime}\right)$ to generate characteristic 220 - and 386-bp PCR products, respectively.

To determine the level of expression of the transgene, the fourth abdominal mammary gland was surgically removed at day 2 of lactation under avertin anesthesia. RNA was prepared from the tissue using the guanidine isocyanate-cesium chloride method (21). The quantity of RNA in each sample was determined spectrophotometrically at $260 \mathrm{~nm}$ and its integrity examined on a $1.25 \%$ agarose/ $0.66 \mathrm{M}$ formaldehyde gel stained with methylene blue.

Transgenic females expressing the transgene were mated repeatedly with normal males and studied during the third lactation. Pups were killed at day 10 of lactation and the fourth abdominal mammary gland was surgically removed from the lactating mice under avertin anesthesia. Five d later, the remaining involuted glands were collected by necropsy. Glands were either fixed in $10 \%$ formalin for histologic examination or frozen in liquid nitrogen for RNA extraction and in situ hybridization.

RNase protection assays. The rat IGF-I antisense RNA probe has been described previously (17). An IGFBP-3 probe was generated by cloning a 255-bp XhoI-BamHI IGFBP-3 cDNA fragment with pGEM7Z, linearizing with XhoI, and using SP6 RNA polymerase to generate a 301-bp antisense riboprobe.

Probes for in situ hybridization. ${ }^{35} \mathrm{~S}$-Labeled antisense RNA complementary to rat IGF-I and IGFBP-3 mRNAs was synthesized from the $5^{\prime}$ IGF-I plasmid described by Roberts et al. (15) and from the plasmid pRBP3-AR (22). The 5' IGF-I plasmid contains a 326-bp EcoRI-Sau3A fragment at the $5^{\prime}$ end of the rat IGF-I cDNA insert in prIGF-I-42. pRBP3-AR contains an ApaI-RsaI fragment (nucleotides 163-861) of a rat IGFBP-3 cDNA clone. Plasmid DNAs were linearized with EcoRI or ApaI and incubated with T7 or T3 RNA polymerase, respectively, in the presence of CTP, GTP, ATP, and $\left[{ }^{35}\right.$ S]UTP. The resulting RNA transcripts were purified on Sephadex G-50 (Boehringer Mannheim, Indianapolis, IN) and used without hydrolysis.

In situ hybridization. Frozen glands that had been stored at $-70^{\circ} \mathrm{C}$ were sectioned using a cryostat. Frozen sections $(10 \mu \mathrm{m})$ were mounted on silane-coated glass slides. The sections were postfixed for $10 \mathrm{~min}$ in $4 \%$ paraformaldehyde in PBS, rinsed in PBS, and dehy- drated. Sections were acetylated, washed in $0.2 \times$ SSC $(1 \times$ SSC contains $0.15 \mathrm{M} \mathrm{NaC1}, 0.015 \mathrm{M}$ Na citrate), and dehydrated. Sections were prehybridized for $2 \mathrm{~h}$ at room temperature in $50 \%(\mathrm{vol} / \mathrm{vol})$ deionized formamide, $0.6 \mathrm{M}$ sodium chloride, $10 \mathrm{mM}$ Tris ( $\mathrm{pH} 7.5$ ), 1 mM EDTA, $0.02 \%$ Ficoll, $0.02 \%$ bovine serum albumin (fraction V), $0.02 \%$ polyvinylpyrrolidone, $0.5 \mathrm{mg} / \mathrm{ml}$ sheared herring sperm DNA, $0.5 \mathrm{mg} / \mathrm{ml}$ yeast total RNA, and $0.05 \mathrm{mg} / \mathrm{ml}$ yeast tRNA. Hybridization was carried out at $50^{\circ} \mathrm{C}$ overnight with ${ }^{35} \mathrm{~S}$-labeled $\left(4 \times 10^{4} \mathrm{cpm} / \mu \mathrm{l}\right)$ RNA probe in prehybridization buffer containing $10 \%$ dextran sulfate, $10 \mathrm{mM}$ DTT, and $0.1 \%$ SDS. After hybridization, the sections were rinsed in $2 \times \mathrm{SSC}$, washed for $30 \mathrm{~min}$ at $45^{\circ} \mathrm{C}$ in $50 \%$ deionized formamide, $1 \times \mathrm{SSC}$, $10 \mathrm{mM}$ DTT followed by $30 \mathrm{~min}$ at room temperature in $0.5 \times \mathrm{SSC}$. Unhybridized probe was removed by treatment with ribonuclease A $(100 \mu \mathrm{g} / \mathrm{ml}$, in $0.5 \mathrm{M} \mathrm{NaC1}, 10 \mathrm{mM}$ Tris, $\mathrm{pH}$ 7.5, $1 \mathrm{mM}$ EDTA) for $30 \mathrm{~min}$ at room temperature followed by a 2-h wash in $0.2 \times \mathrm{SSC}$ at $55^{\circ} \mathrm{C}$ and dehydration through ethanol. Sections were coated with autoradiographic emulsion (Kodak NTB2) and stored at $4^{\circ} \mathrm{C}$ for $72 \mathrm{~h}$ before development, fixation, and counterstaining in hematoxylin.

Histology. Sections of mouse mammary glands were surgically excised and immediately placed in neutral buffered formalin. Paraffin sections were prepared and stained with hematoxylin and eosin. Sections were histologically evaluated for lobular proliferation, secretory activity, and for changes in supporting stroma and adipose tissue. Sections showing involutional change were evaluated for residual acinar proliferation and secretory change, extent of ducto-lobular lumenal secretions, apoptosis of ducto-lobular epithelial and myoepithelial cells, and nature and extent of host inflammatory response. Apoptosis was identified by the presence of prominent cytoplasmic eosinophilia, nuclear shrinkage and fragmentation, and apoptotic bodies. In addition, serial sections were prepared for specific staining for apoptosis using erminal deoxy-ribonucleotidyl transferase (TdT) and biotinlabeled NTPs. Avidin-bound Fuchsin red was used for identification of apoptotic nuclei (Molecular Histology Labs Inc., Gaithersburg, MD).

Immunohistochemistry. 3-4- $\mu \mathrm{m}$ sections were cut from formalinfixed wax-embedded tissue, baked at $60^{\circ} \mathrm{C}$ for $1 \mathrm{~h}$ and deparafinized in xylene and reverse grade alcohols. Antigen retrieval was performed using Citra solution HK086-9K; BioGen. Labs, San Ramon, CA) with a 1:10 dilution of the stock and microwave digestion for 3 min, twice, with replacement of distilled water due to loss. Blocking of endogenous peroxidase was achieved by incubation in $\mathrm{H}_{2} \mathrm{O}$ /methanol for $10 \mathrm{~min}$. The immunohistochemical assay was initiated by blocking the sections with 1:100 goat serum and sequential incubation with avidin and biotin (BioGenex Labs). The primary antibody (antiIGF-I) was kindly obtained from the National Hormone and Pituitary Program via Ogden Bio Services Corp. (Rockville, MD) and was incubated overnight at $4^{\circ} \mathrm{C}$ followed by several PBS washes. Link antibody (Biotinylated goat anti-mouse), Streptavidin (both Dako Corp., Carpinteria, CA) were incubated for $30 \mathrm{~min}$ with intervening PBS washes. Colorization was performed by DAB (Dako Corp.).

\section{Results}

Generation of mice carrying the rat IGF-I and human IGFBP-3 transgenes. Transgenic mice carrying the rIGF-I and hIGFBP-3 transgenes (WAP-IGF-I and WAP-BP-3) were identified by PCR analysis of genomic DNA obtained from the tail. Since the WAP gene is expressed almost exclusively in mammary tissue and is induced to very high levels at midpregnancy and throughout lactation, we identified lines with high expression of the transgenes by examining mammary tissue at early stages of lactation. Using Northern analysis and solution hybridization/ RNase protection assays, we found expression of two mRNAs for rIGF-I, one of $\sim 1.5 \mathrm{~kb}$ and a lesser band with higher molecular weight on Northern blot (Fig. 1 left). Similarly, two mRNAs for hIGFBP-3 were noted on Northern blots, the major band 
of $\sim 2.5 \mathrm{~kb}$ and a minor higher molecular weight band (Fig. 1, right). Solution hybridization/RNase protection assays confirmed the specific expression of IGF-I and IGFBP-3 (Fig. 2, $A$ and $B$ ). Four lines of WAP-IGF-I and seven lines of WAPBP-3 were established and tested. Studies were performed primarily with animals from generation 3 . Mice with the greatest degree of expression were chosen for further study (1939 and 767 for rIGF-I and hIGFBP-3 transgenes, respectively); however, identical results were obtained in two other lines of each transgene. In total, at least 10 animals from each transgenic line (WAP-IGF-I and WAP-BP-3) were studied. As determined by solution hybridization/RNase protection assay, expression of the transgene was confined to mammary tissue; its pattern of expression followed the known pattern for WAP gene expression, i.e., high from midpregnancy, lactation, and decreasing progressively during involution. No expression of the transgenes were detectable in liver, spleen, kidney, and brain in lineages 767 and 1939. No expression was seen in transgenic virgins. Protein expression of hIGFBP-3 was determined on whole-tissue extracts using a polyclonal antibody (UBI). A single band of $\sim 48 \mathrm{kD}$ was detected on Western blots, representing hIGFBP-3, in WAP-BP-3 transgenic mice, whereas no band was detected in control mice (data not shown). Western blot analysis was unsuccessful for detection of IGF-I peptide. Females from both the high-expressing WAP-IGF-I line 1939 and the WAP-BP-3 line 767 delivered litters of normal size and were able to lactate and raise their litters repeatedly. This clearly demonstrated that mammary gland development during pregnancy and functional terminal differentiation of alveolar epithelial cells were unimpaired in the presence of excess IGF-I or IGFBP-3.

To localize expression of the transgene in lactating mammary glands, we performed in situ hybridization to sections of the transgenic glands using ${ }^{35} \mathrm{~S}$-labeled RNA probes for IGF-I or IGFBP-3. Both transgenes were expressed at high levels in epithelial cells of alveoli and ducts. Myoepithelial cells and stromal cells showed no detectable signal at these exposure times for either transgene. Hybridization of IGF-I on sections of mammary glands from wild-type mice or from mice carrying the IGFBP-3 transgene showed no signal above background after identical exposure time to radiographic emulsion. Simi-

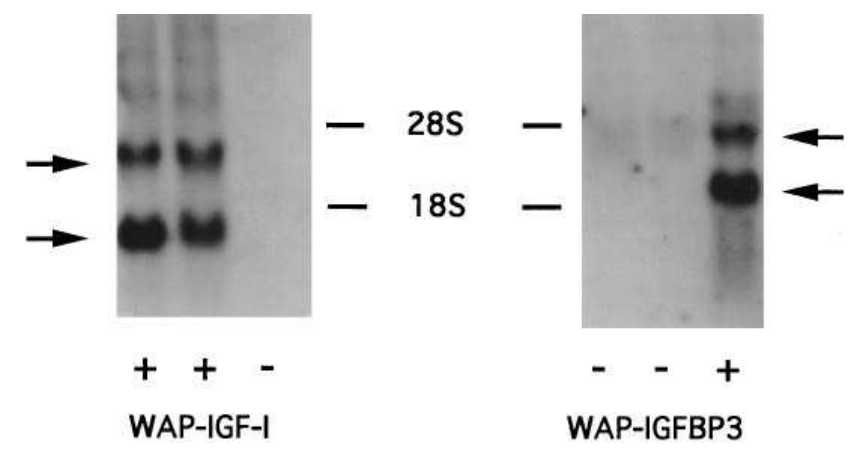

Figure 1. Northern blot analyses of WAP-IGF-I and WAP-IGFBP-3 transgene expression. mRNA extracted from mammary gland from individual mice carrying the transgene $(+)$ and nontransgenic animals $(-)$ were probed by Northern blot analysis using labeled cDNAs specific for rIGR-I (left) and hIGFBP-3 (right). The upper band is commonly seen in these transgenic animals and probably represents downstream polyA site usage. The results are representative of 8-10 examples of mice expressing these transgenes.
A

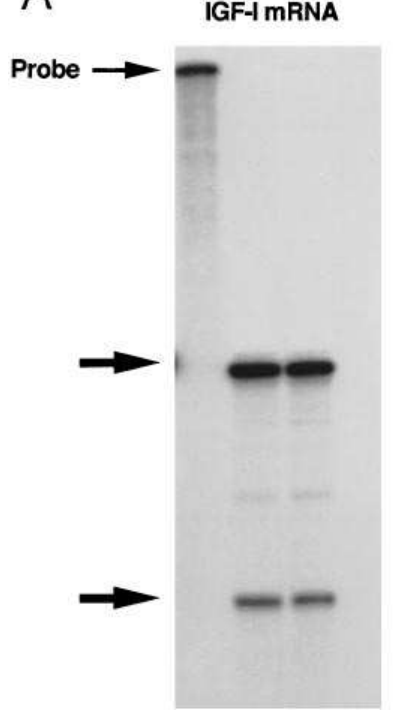

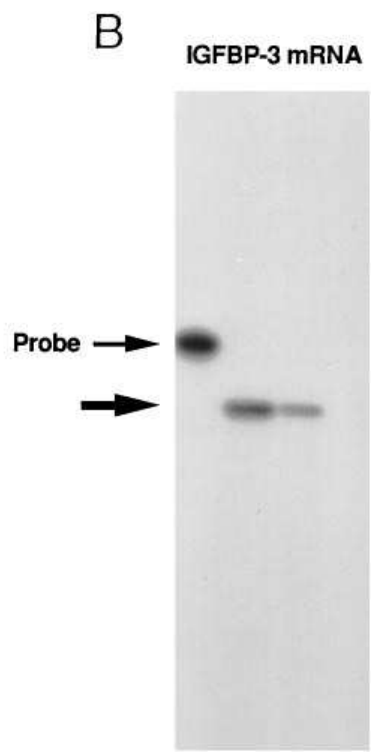

Figure 2. Solution hybridization/RNase protection assays. Using specific probes (described in Methods), assays were performed to confirm the specificity of the expression of the transgenes. Each lane represents RNA from tissue obtained from separate transgenic animals. In each lane the appropriate protected band(s) was (were) seen. The probe for IGF-I is $\sim 690 \mathrm{bp}$ and the protected bands are $\sim 280 \mathrm{bp}$ and $\sim 180 \mathrm{bp}$. The probe for IGFBP- 3 is $\sim 310 \mathrm{bp}$ and the protected bands are $\sim 280 \mathrm{bp}$. No protected bands were seen in control nontransgenic mice (data not shown).

larly, hybridization of IGFBP-3 to sections of mammary glands from wild-type mice or from mice carrying the IGF-I transgene was low or undetectable (Fig. 3, $A$ and $B$ ).

Histology. IGF-I peptide was detected by immunohistochemical analysis in the cytoplasm of alveolar epithelial cells as well as in the lumens of sections from mammary glands from WAP-IGF-I transgenic animals (data not shown). Nontransgenic controls and WAP-BP-3 transgenic animals were negative for IGF-I peptide. Similar data were not obtainable using the IGFBP-3 antibody.

Histological analyses of mammary tissue from animals at day 10 of lactation revealed that the fat pads of both the WAPIGF-I and WAP-BP-3 transgenic mice and nontransgenic littermates were filled with lobulo-alveolar structures (Fig. 4, $A$, $C$, and $E$ ). The alveolar cells were cuboidal with prominent cytoplasmic vacuoles and surrounded large lumina, features indicative of extensive secretion. Although mammary tissue in transgenic mice was able to synthesize and secrete sufficient milk to maintain a litter, the alveoli appeared smaller than those found in nontransgenic littermates (Fig. 4, compare $C$ and $E$ with $A$ ).

To evaluate the role of persistent IGF-I and IGFBP-3 synthesis after weaning, pups were removed from their mothers at day 10 of lactation, and mammary tissue was evaluated after $5 \mathrm{~d}$ of involution. While extensive remodeling of mammary tissue occurred in control mice, a modified involution was seen in both transgenic mice. Control mice exhibited an active cellular involuntionary pattern in which most of the lobules and alveoli had collapsed. Some degree of residual lobular secretory hyperplasia was seen with ductal lumenal secretory material containing apoptotic cells and bodies (Figs. $4 B$ and $5 A$ ). The al- 

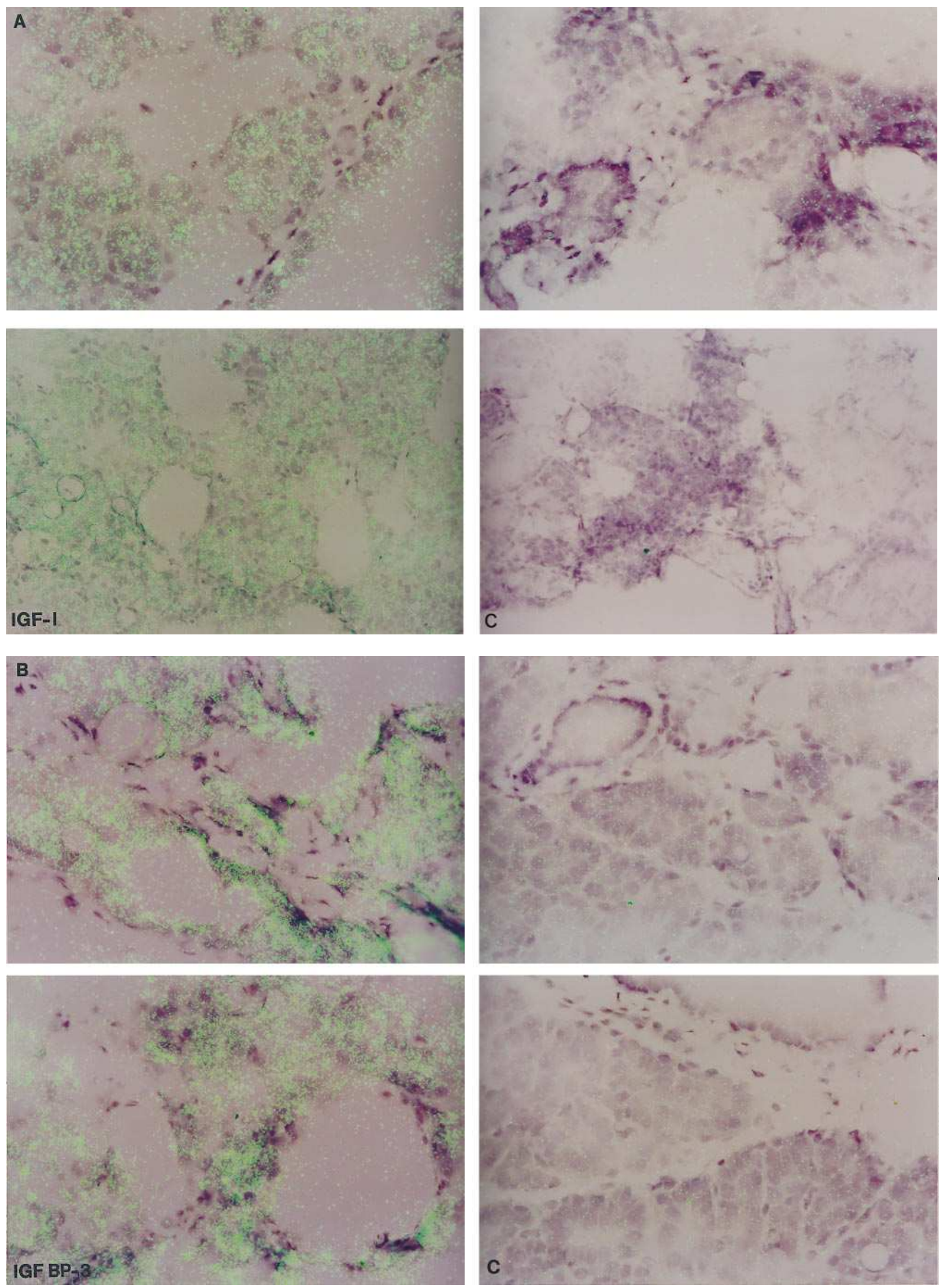

Figure 3. In situ hydridization. Frozen mammary gland, from lactating animals, was sectioned using a cryostat and hybridized using specific riboprobes for IGF-I and IGFBP-3. ( $A$ ) Upper four panels depict two examples of mice expressing the WAP-IGF-I transgene (left) and two controls $(r i g h t) .(B)$ Lower four panels depict two mice expressing WAP-IGFBP-3 transgenes (left) and controls (right). 

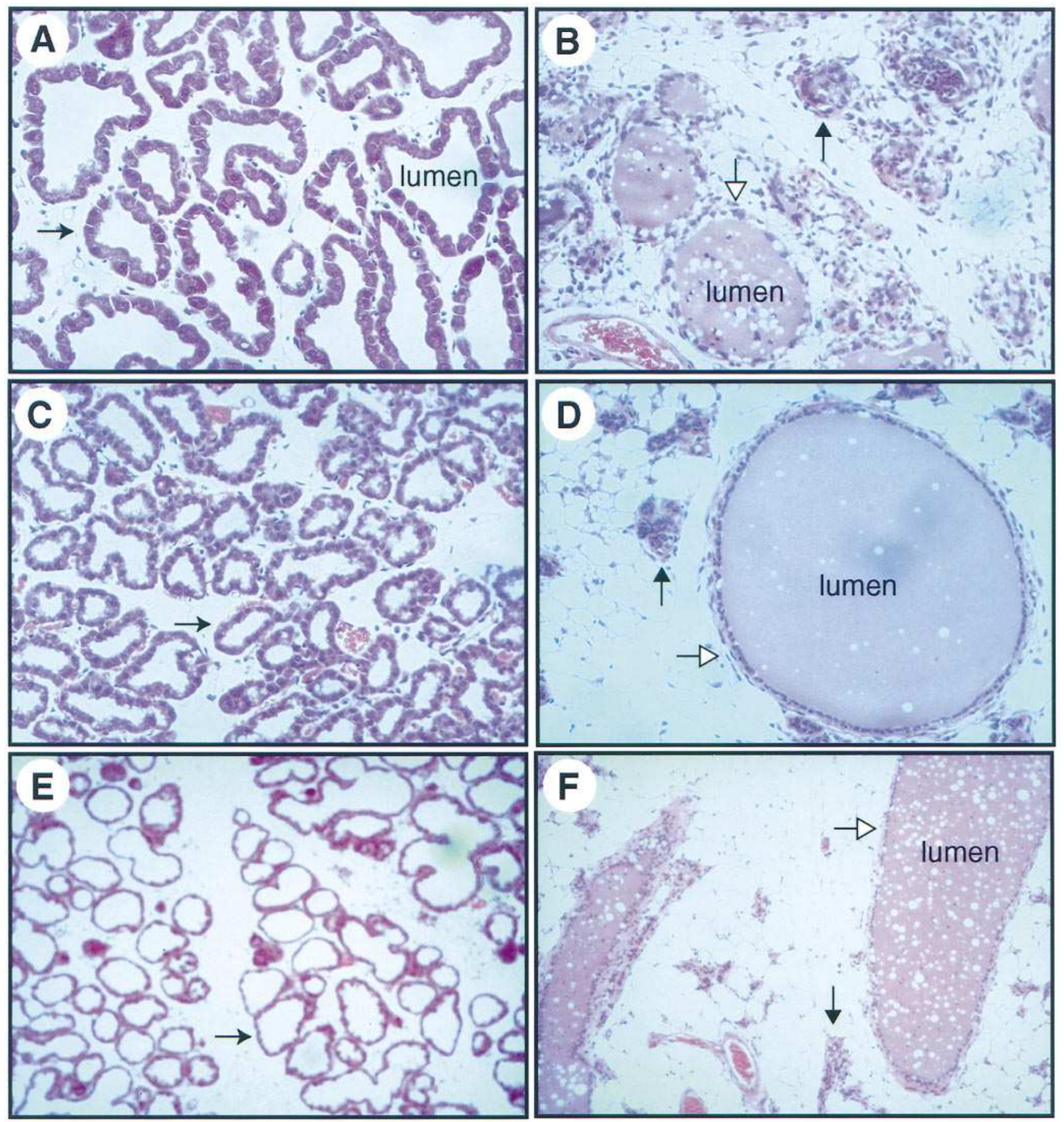

Figure 4. Histological analysis of mammary tissue during lactation and involution. Mammary tissue biopsies were taken from nontransgenic $(A)$, WAP-IGF-I $(C)$, and WAP-BP-3 $(E)$ mice at day 10 of lactation, and they were fixed, sectioned, and stained with hematoxylin and eosin. The arrows indicate individual alveoli. An alveolar lumen is marked in $A$. The pups were removed from these mice at this time, and mammary tissue was analyzed after $5 \mathrm{~d}$. $(B)$ Nontransgenic, $(D)$ WAP-IGF-I, $(F)$ WAP-BP-3. The solid arrows in $B, D$, and $F$ point to collapsed alveoli which are being remodeled. The open arrow in $B$ points to an alveolus with a disrupted basement membrane and apoptotic cells. The open arrow in $D$ points to an intact alveolus. The open arrow in $F$ indicates an extended alveolus. The magnification was 200-fold.

veolar cells of the lobular units showed the most pronounced apoptotic changes, present to a lesser extent within the ductal epithelial cells (Fig. $4 \mathrm{~B}$ ). These mammary glands also showed a peri-lobular stromal proliferation, inflammatory cell host response, and prominent lumenal microcalcifications. Neutrophils were present within some lobular units, and scattered mononuclear cells including plasma cells were present in the peri-lobular stroma.

The IGF transgenic mice demonstrated a markedly different histologic pattern of involution. Extensive lobular-alveolar units remained with lobular secretory activity and without the ductal apoptotic cells within the lumenal secretions (Fig. $4 \mathrm{D}$ 

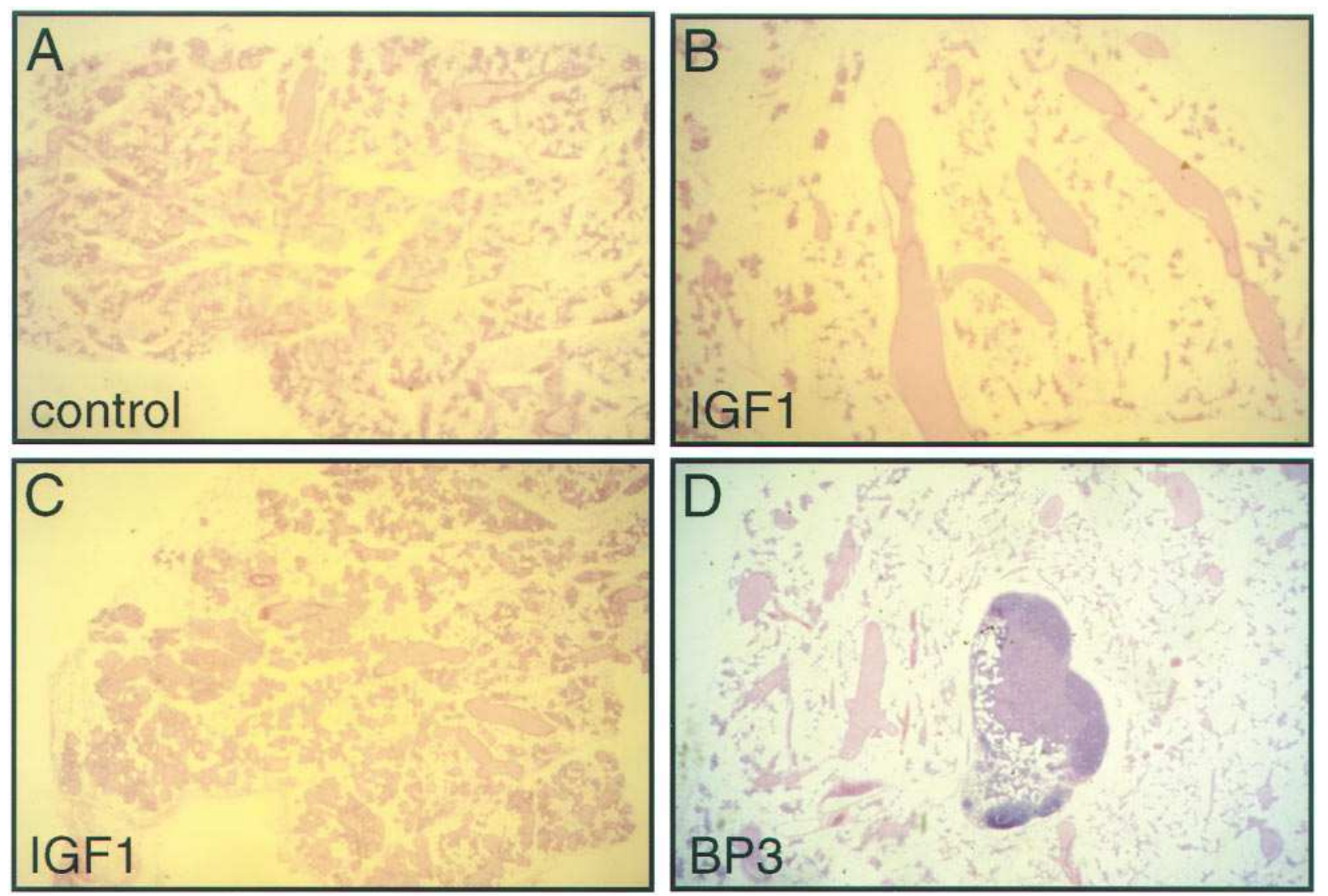

Figure 5. The magnification was 50-fold. Histological analysis of mammary tissue remodeling after $5 \mathrm{~d}$ of involution. $(A)$ Mammary tissue from nontransgenic mice; $(B$ and $C$ ) WAP-IGF-I mice; and $(D)$ WAP-BP-3 mice. This low magnification illustrates the extent of remodeling in the different mice. While mammary tissue from nontransgenic mice has been remodeled to a large extent, lobulo-alveolar structures persist in WAPIGF-I and WAP-BP-3 mice. Two WAP-IGF-I transgenic mice are shown to illustrate the variability.

and Fig. $5 B$ and $C$ ). The extent of apoptosis of the lobular epithelial and myoepithelial cells was considerably less and there was a diminution of the peri-lobular proliferative response. The host inflammatory reaction was relatively muted and there was a marked relative decrease in the lumenal microcalcifications.

Similarly (though to a slightly lesser extent), remodeling of mammary tissue in the WAP-BP-3 mice was retarded (Fig. $4 F$ and Fig. $5 \mathrm{D}$ ). None of the cases (normal controls, WAP-IGF-I transgenes, or WAP-BP-3 transgenes) showed any degree of intraductal or intralobular hyperplasia characterized by a proliferation and stratification of epithelial cells above the basement membrane with filling of the ducto-lobular lumen. No cytologic abnormalities nor neoplastic features were detected.

While the presence of apoptotic cells was widespread in nontransgenic mice, less apoptosis was observed in the alveoli of both WAP-IGF-I and WAP-BP-3 mice (Fig. 6). In control mice some alveoli were still visible at day 5 of involution, but their epithelial cell layer was already disrupted and dead cells had been shed into the lumen (Fig. $6 A$ ). Using a TUNEL assay we could show extensive cell death in remodeled alveoli of nontransgenic mice (Fig. $6 A$ ). In contrast, apoptotic cells were rare in retained alveoli in the transgenic mice (Fig. $6 B$ and $C$ ).

In addition to an incomplete involution of the lobular-alveolar compartment, ductal hypertrophy was observed in WAPIGF-I and WAP-BP-3 mice (Fig. 5, $B-D$ ). The hypertrophic ducts were often filled with a lipid-rich secretion not seen in nontransgenic mice. The hypertrophic ducts were futher characterized by a thickened layer of collagen and extracellular matrix surrounding the flat epithelial cells (Figs. 4 and 5).

\section{Discussion}

While prolactin is critically important for mammary lobuloalveolar development, milk gene expression, and milk secretion $(23,24)$, hGH can substitute for Prl since it can bind to lactogenic receptors. However, nonhuman GH stimulates mammary development $(6,25)$ acting via specific $\mathrm{GH}$ receptors (26). That IGF-I may be the mediator of GH-dependent mammary effects was postulated after the finding that $\mathrm{GH}$ stimulates mammary IGF-I mRNA (6) and that IGF-I can affect mammary gland development when administered together with estradiol to hypophysectomized, castrated rats (27).

Involution of the mammary gland after pregnancy and lactation involves cell death and remodeling and is associated with an increase in extracellular matrix degrading enzymes (28). While the role of IGF-I and the IGFBPs in mammary development during pregnancy remains controversial (7), its role in regulating apoptosis seems more substantiated (29). In this study we were able to evaluate the effect(s) of locally produced IGF-I and IGFBP-3 on mammary gland development during pregnancy and involution. High levels of rIGF-I and hIGFBP-3, as determined by Northern blot, RNase protection 

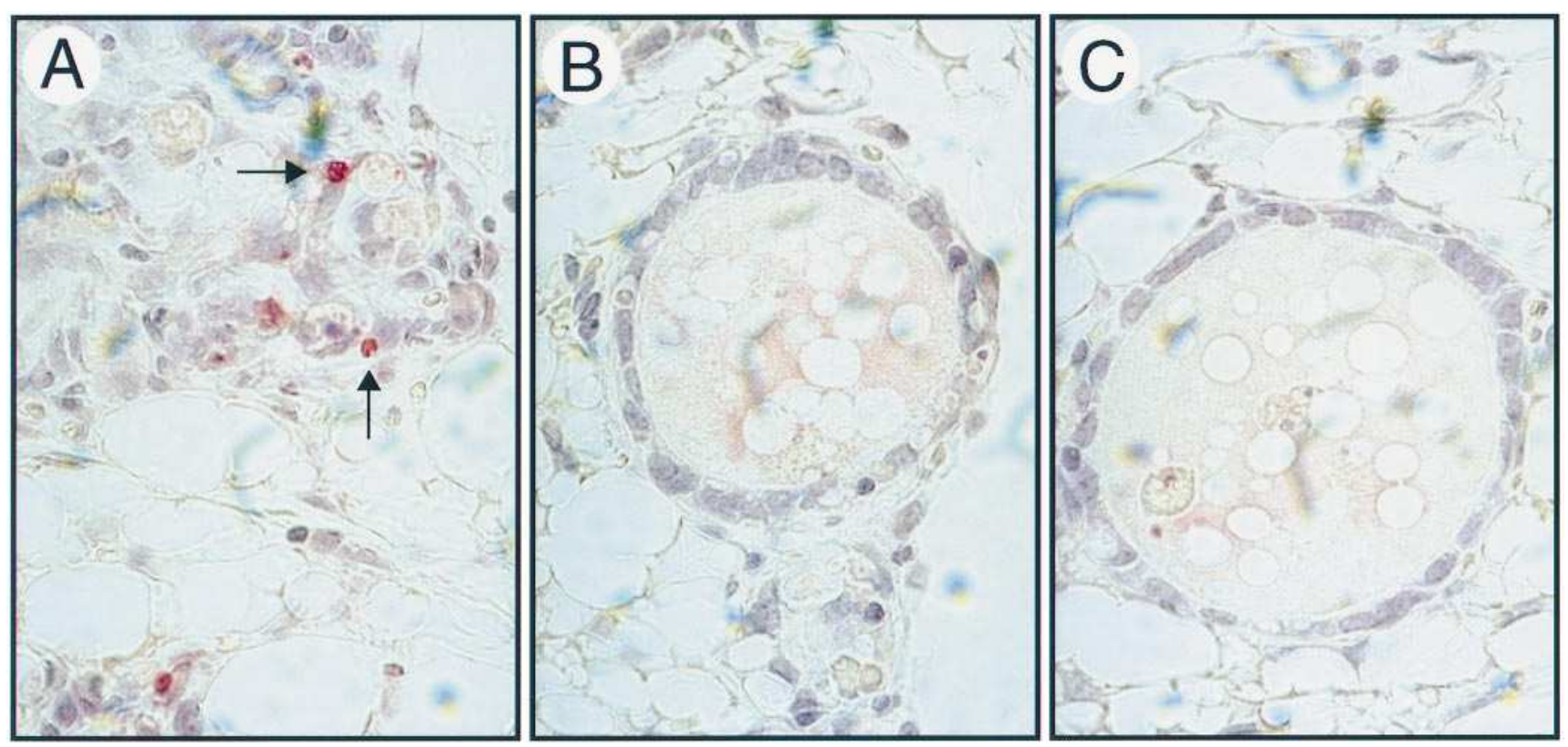

Figure 6. Staining for apoptotic cells (solid arrows) using TdT and an avidin-fuchsin stain to identify biotin-bound NTFs (see Methods). The results are representative of at least three mice per lane. $A$, control; $B$, WAP-IGF-I; and $C$, WAP-IGFBP-3.

assays, and Western blot analysis and immunohistochemical analysis, were expressed in mammary glands in transgenic mice. In situ hybridization confirmed these results and demonstrated that expression of each transgene was localized to alveoli. Lubulo-alveolar epithelial cells are the predominant cell type in the glands during late pregnancy and early lactation. Since the WAP gene promoter is specifically active in these cells during this period, IGF-I and IGFBP-3 were targeted to this cell population.

The presence of large quantities of rat IGF-I and human IGFBP-3 in mammary alveolar cells in transgenic mice did not alter mammary development during pregnancy and the glands were fully functional. Indeed, mothers from both transgenic lines delivered litters of normal size and nursed their young normally. This is in sharp contrast to previous studies in which expression of other regulatory proteins such as WAP actually resulted in impaired mammary development and a "milchlos" phenotype (19). The only structural difference seen during lactation was an overall smaller size of the alveoli in transgenic animals.

Clearly, the most significant and predominant finding of this study was the marked effect of overproduction of mammary gland IGF-I and IGFBP-3 on the involutionary process after weaning. Thus, the continued synthesis of IGF-I in particular and, to a slightly lesser extent, IGFBP-3 inhibited the gland from undergoing programmed remodeling and apoptosis. Intact alveoli that secreted milk persisted in the WAPIGF-I mice for several days after weaning. This suggests that the continued synthesis of IGF-I modulates alveolar cells from entering apoptotic pathways. Since IGF-I gene expression in the mammary gland of normal animals is very low during lactation (30), the inhibition of apoptosis and the delay of the involutionary phase seen in IGFBP-3 transgenic mice may be an IGF-I-independent effect. Alternatively, IGFBP-3 may accumulate IGF-I from the circulation and enhance its effects (30). These data also emphasize the importance of local growth reg- ulators in the maintenance of secretory alveolar cells. Clearly, remodeling of mammary tissue in the WAP-IGF-I and WAPIGFBP-3 mice is not completely inhibited. While some alveoli are fully maintained, others collapse and are remodeled in a similar time frame as in nontransgenic controls. This is probably the result of mosaic expression of the transgene or a compensatory mechanism by other cellular and molecular factors involved with involution and remodeling. In some cases, transgenes containing the WAP gene promoter are not expressed equally well in alveolar cells. For example, expression of a WAP-p53 hybrid gene in mice resulted in a mosaic pattern of premature involution that was reflective of the transgene expression (31). In a recent study by Hadsell et al. (32), transgenic expression of des(1-3)hIGF-I in the mammary gland similarly resulted in reduced mammary involution after lactation.

In summary, we have used a transgenic approach to demonstrate that IGF-I and IGFBP-3 influence the involutionary phase and remodeling of mammary tissue after lactation by inhibiting cellular apoptosis. The potential role of this family of growth factors and their binding proteins in mammary development and milk production therefore remains to be further investigated.

\section{References}

1. Rillema, J.A. 1994. Development of the mammary gland and lactation. Trends Endocrinol. Metab. 5:149-154.

2. Forsyth, I.A. 1989. Growth factors in mammary gland function. J. Reprod. Fertil. $85: 759-770$.

3. Forsyth, I.A. 1991. The mammary gland. Bailliere's Clin. Endocrinol. Metab. 5:809-832.

4. Daniel, C.W., and G.B. Silberstein. 1987. Postnatal development of the rodent mammary gland. In The Mammary Gland. M.C. Neville and C.W. Daniel, editors. Plenum Publishing Corp., New York. 1-36.

5. Lyons, W.R., C.H. Li, and R.F. Johnson. 1958. The hormonal control of mammary growth and lactation. Recent Prog. Horm. Res. 14:219-254.

6. Kleinberg, D.L., R. Weifeng, V. Catanese, C.B. Newman, and M. Feldman. 1990. Non-lactogenic effects of growth hormone on growth and insulin- 
like growth factor-I messenger ribonucleic acid of rat mammary gland. Endocrinology. 126:3274-3276.

7. Plaut, K., M. Ikeda, and B.K. Vonderhaar. 1993. Role of growth hormone and insulin-like growth factor-I in mammary development. Endocrinology. 133: $1843-1848$.

8. Rechler, M.M. 1993. Insulin-like growth factor binding proteins. Vitam. Horm. 47:1-99.

9. Donovan, S.M., R.L. Hintz, and R.G. Rosenfeld. 1995. Investigation into the potential physiological sources of rat milk IGF-I and IGF-binding proteins. J. Endocrinol. 145:569-578.

10. Grosvenor, C.E., M.F. Picciano, and C.R. Baumrucker. 1993. Hormones and growth factors in milk. Endocr. Rev. 14:710-728.

11. Yee, D., K.J. Cullen, S. Paik, J.F. Perdue, B. Hampton, A. Schwartz, M.E. Lippman, and N. Rosen. 1988. Insulin-like growth factor II mRNA expression in human breast cancer. Cancer Res. 48:6691-6696.

12. Yee, D., S. Paik, G.S. Lebovic, R.R. Marcus, R.E. Faconi, K.J. Cullen, M.E. Lippman, and N. Rosen. 1989. Analysis of insulin-like growth factor I gene expression in malignancy: evidence for a paracrine role in human breast cancer. Mol. Endocrinol. 3:509-517.

13. Prosser, C.G., M.D. Baucells, and I.R. Fleet. 1992. Transfer of insulinlike growth factors I and II from plasma to lymph in young goats. Exp. Physiol. 77:575-585.

14. Campbell, P.G., T.C. Skaar, J.R. Vega, and C.R. Baumrucker. 1991. Secretion of insulin-like growth factor-I (IGF-I) and IGF-binding proteins from bovine mammary tissue in vivo. J. Endocrinol. 128:219-228.

15. Roberts, C.T., Jr., S.R. Lasky, W.L. Lowe, Jr., W.T. Seaman, and D. LeRoith. 1987. Molecular cloning of rat insulin-like growth factor I complementary deoxyribonucleic acids: differential messenger ribonucleic acid processing and regulation by growth hormone in extrahepatic tissues. Mol. Endocrinol. 1: 243-248.

16. Shimatsu, A., and P. Rotwein. 1987. Sequence of two rat insulin-like growth factor I mRNAs differing within the 5'-untranslated region. Nucleic Acids Res. 15:7196-7202.

17. Adamo, M.L., H. Ben-Hur, C.T. Roberts, Jr. and D. LeRoith. 1991. Regulation of start site usage in the leader exons of the rat IGF-I gene by development, fasting and diabetes. Mol. Endocrinol. 5:1677-1686.

18. Chen, J.-C., Z.-M. Shao, S. Sheikh., A. Hussain, D. LeRoith, C.T. Roberts, Jr., and J.A. Fontana. 1994. Insulin-like growth factor-binding protein enhancement of insulin-like growth factor-I (IGF-I)-mediated DNA synthesis and IGF-I binding in a human breast carcinoma cell line. J. Cell. Physiol. 158:69-78.

19. Burdon, T., L. Sankaran, R.J. Wall, M. Spencer, and L. Henninghausen. 1991. Expression of a whey acidic protein transgene during mammary development: evidence for different mechanisms of regulation during pregnancy and lactation. J. Biol. Chem. 266:6909-6914.
20. Gordon, J.W. 1992. Production of transgenic mice. In Methods in Enzymology. Guide to Techniques in Mouse Development. Vol. 225. P. W. Wasserman and M. L. Depamphilis, editors. Academic Press, New York. 747-770.

21. Cathala, G., J.F. Savouret, B. Mendez, B.L. West, M. Karin, J.A. Martial, and J.D. Baxter. 1983. A method for isolation of intact, translationally active ribonucleic acid. $D N A(N Y)$. 2:329-335.

22. Shimasaki, S., A. Koba, M. Mercado, M. Shimonaka, and N. Ling. 1989. Complementary DNA structure of the high molecular weight rat insulin-like growth factor binding protein (IGF-BP3) and tissue distribution of its mRNA. Biochem. Biophys. Res. Commun. 165:907-912.

23. Ichinose, R.R., and S. Nanci. 1964. Lobuloaveolar differentiation in mouse mammary tissues in vitro. Science (Wash. DC). 145:496-497.

24. Ichinose, R.R., and S. Nandi. 1966. Influence of hormones on lobuloalveolar differentiation of mouse mammary gland in vitro. J. Endocrinol. 35:331340 .

25. Silberstein, G.B., and C.W. Daniel. 1987. Investigation of mouse mammary ductal growth regulation using slow-release plastic implants. J. Dairy Sci. 70:1981-1990.

26. Hauser, S.D., M.F. McGrath, R.J. Collier, and G.G. Krivi. 1990. Cloning and in vivo expression of bovine growth hormone receptor mRNA. Mol. Cell. Endocrinol. 72:187-200.

27. Ruan, W., C.B. Newman, and D.L. Kleinberg. 1992. Intact and aminoterminally shortened forms of insulin-like growth factor-I induce mammary gland differentiation and development. Proc. Natl. Acad. Sci. USA. 89:1087210876.

28. Strange, F., F. Li, S. Saurer, A. Burkhardt, and R.R. Friis. 1992. Apoptotic cell death and tissue remodeling during mouse mammary gland involution. Development (Camb.). 115:49-58.

29. Harrington, E.A., M.R. Bennett, A. Fanidi, and G.I. Evan. 1994. c-Mycinduced apoptosis in fibroblasts is inhibited by specific cytokines. EMBO (Eur. Mol. Biol. Organ.) J. 13:3286-3295.

30. Marcotty, C., F. Frankenne, S. Meuris, and G. Hennen. 1994. Immunolocalization and expression of insulin-like growth factor I (IGF-I) in the mammary gland during rat gestation and lactation. Mol. Cell. Endocrinol. 99: 237-243.

31. Li, B., N. Greenberg, L.C. Stephens, R. Meyn, D. Medina, and J.M. Rosen. 1994. Preferential overexpression of a 172Arg $\rightarrow$ Leu mutant p53 in the mammary gland of transgenic mice results in altered lobuloalveolar development. Cell Growth \& Differ. 5:711-721.

32. Hadsell, D.L., N.M. Greenberg, J.M. Fligger, C.R. Baumrucker, and J.M. Rosen. 1996. Targeted expression of des(1-3) human insulin-like growth factor-I in transgenic mice influences mammary gland development and IGFbinding protein expression. Endocrinology. 137:321-330. 